Colloque C2, suppl. au Journal de Physique II; Vol. 1, septembre 1991

\title{
USE OF THE HAZOP ANALYSIS FOR EVALUATION OF CVD REACTORS
}

\author{
W.W. CRAWFORD, J.R. ZUBER and W.R. KNOLLE \\ $A T \& T$ Bell Laboratories, 555 Union Boulevard, \\ Allentown, PA 18103, U.S.A
}

\begin{abstract}
Before equipment is installed at AT\&T Bell Laboratories, Allentown, a hazard and operability (HAZOP) analysis is done. Through a systematic process, a team leader guides a group of knowledgeable individuals through the equipment design to discover the hazards and the operating range of the equipment. During this HAZOP analysis, the equipment engineer responsible for the CVD process becomes aware of all aspects of the equipment from the electrical and chemical hookup of the process chamber to the treatment of the effluent. At our facility, HAZOP analysis has proven to be an effective tool. We present a sample HAZOP analysis for an MOCVD installation along with the short, easy-to-use questionnaire that the responsible engineer completes before the HAZOP analysis begins.
\end{abstract}

\section{Introduction}

\subsection{Device Development Line}

The Allentown, Pennsylvania, branch of AT\&T Bell Laboratories is a development lab where integrated circuit processes are transferred to manufacturing. Our device development line consists of one clean room where wafer cleaning, thin film and metal deposition, plasma etching, and oxidation are done. Gases such as silane, phosphine, ammonia, nitrogen trifluoride, boron trichloride, hydrogen chloride, and hydrogen bromide are routinely used. There are two adjacent clean rooms where ion implantation and photolithography are located. Toxic gases extend to photolithography where fluorine is used for the excimer laser lithographic tool. In ion implantation we use boron trifluoride and silicon tetrafluoride but use solid arsenic and phosphorus rather than arsine and phosphine. Clearly, many processes involving hazardous materials are required for the fabrication of an integrated circuit.

\subsection{Development Environment}

In a development environment there are four axioms: (1) Nothing is temporary; (2) Designs will be copied; (3) Communications will break down; and (4) Systems will not be maintained. The full impact of these four axioms emerges when we reflect on the hazardous gases in use. For example, silane is unreliably pyrophoric and does detonate. Is there anything that can be applied to processes that have evolved from a development environment to assess their safety or do we simply rely on the equipment manufacturer?

Equipment manufacturers do build safe equipment and processes. However, it is our responsibility to ensure that our safety standards are met and that the equipment will operate safely under the conditions presented by our facilities. For example, polypropylene is forbidden as a material of construction for equipment in our cleanroom because of flammability. Instead, we use polyvinyl chloride which will not burn by itself. Our facility has no easy access to an HF treatment system and so 
Our experience has taught us that a process hazard review (PHR) gives us a substantive foundation for judging that the process equipment will operate safely and efficiently. In this paper we present why we rely on PHRs at AT\&T Bell Laboratories and two ways the PHR is conducted. As a specific example, we present a PHR for a commercially available MOCVD reactor using "What if?" and "HAZOP" analyses. The strengths and weaknesses of each analysis are presented.

\section{Process Hazard Review}

\subsection{Why a PHR?}

The accident rates for the semiconductor industry and our development line are low and so why do anything at all? The reason is that controlling accident frequency does not control accident severity. We have only to look at unfortunate experiences such as the explosion of a silane cylinder at Gollob Analytical Labs ${ }^{[1]}$ and the Challenger explosion. ${ }^{[2]}$ Neither had experienced a catastrophe of this severity before.

Furthermore, a recognized safety management consultant Dan Petersen, working from insurance industry statistics, points out that "Certain sets of circumstances can be predicted to produce severe injuries. These circumstances can be identified and controlled." ${ }^{[3]}$ We can identify these circumstances provided that we ask the right questions.

The PHR is an attempt to make sure that the right questions are asked. In the United States, the American Institute of Chemical Engineers ${ }^{[4][5][6]}$ has developed and published PHR techniques to address plant design issues in the chemical process industry. We have taken these procedures and adapted and applied them to our development operation which can be considered a very small part of the chemical industry. While our quantity of chemical use is small compared to a chemical process plant, we work in buildings shared with a large population of non-chemical workers. Because they may be affected by an accident, the PHR is as essential as in any large-scale chemical processing plant.

\subsection{What is a PHR?}

A PHR is a systematic peer review of equipment and processes with a potential for an accident that may produce personal injury or property damage. The greatest amount of time and attention is given to those processes with the most serious hazard potential. For example, all processes using hydride gases are subject to an annual PHR at our facility.

The individual engineer responsible for the integrated circuit process is also responsible for the PHR. There is no separate staff with responsibility to review and change equipment and processes. Figure 1 shows the PHR questionnaire that the responsible engineer must complete. The PHR questionnaire leads the engineer through a series of safety and health questions. When completed, this questionnaire along with a copy of flow diagrams and material safety data sheets for the chemicals involved forms a package that will be used by the PHR team.

The PHR team consists of five to seven knowledgeable people who are responsible for reviewing the information provided and identifying potential hazards. Experience has shown that a PHR cannot be done alone: the committee must brainstorm to achieve insight.

The responsible engineer must present all relevant process and equipment information. A team leader is required who will ask questions focussed on identifying hazards and not engineering solutions. The team must not yield to the temptation to solve specific problems rather than look at the overall process. The other members of the group are drawn from facilities, safety, and process engineering. All must be knowledgeable enough to understand the process, identify potential hazards, and ask meaningful questions. 


\section{Figure 1}

PROCESS HAZARD REVIEW QUESTIONNAIRE

Purpose: To ensure that potentially hazardous experiments/operations have been reviewed and all equipment inspected from a safety aspect by other knowledgeable individuals.

HAZARD CLASSIFICATION:

DATE:

MTS/Functional Engineer:

OFFICE LOCATION: ROOM: EXTENSION:

DEPT PROCESS EXISTING SINCE: OR PROPOSED DESIGN DATE:

1. Proposed experiment or process and equipment to be used:

2. The equipment is, or will be, in Building Room Extension:

3. (a) The following hazardous/toxic materials are used, with typical quantity/run, no. of runs/week:

3. (b) Equipment hazards (mechanical, electrical, pressure, thermal or cryogenic and radiation)

4. The following safety items are incorporated into the equipment

(a) Automatic safety devices (limit switches, pressure relief valves, fail safe shutdown for electrical, gas water or exhaust failure, etc.):

(b) Protection for operating personnel: (shields, guards, interlocked switches)

(c) Signal alarms/devices: (Exhaust failure alarms, toxic gas monitors, overload alarms for high temperature, pressure, flow, etc.:

Signs for what do to if alarm sounds:

(d) Safety feature tests: how, by whom, and how often tested?

5. Under what conceivable conditions or circumstances can hazardous/toxic materials be released, or an out-of-control reaction occur?

Are there exhausted chem. hoods/gas cabinets, scrubbers, blast shields, sprinklers, etc., for above?

6. Describe emergency shutdown or response procedures for above:

7. What security and access restrictions are needed?

\section{Spill control procedures:}

8. Specify the Personal Protective Equipment (PPE) required for each hazardous procedure:

Special training and operating restrictions:

9. Operating, servicing and cleaning instructions are, or will be, located in (attach copy, if available):

Location of logs (monitors, tests, incidents, modifications)

10. Waste disposal procedures:

Salvage restrictions for the equipment:

11. The following literature describes similar experiments or equipment:

Are you aware of any published/private communications describing accidents with similar experiments or equipment? Describe:

12. (Optional) The functional engineer has informally reviewed this questionnaire with:

* Attach a copy of flow diagram and MSDS (Material Safety Data Sheet) for all chemicals and gases used. 


\subsection{How is the PHR done}

Several methods are available to give structure to a PHR. ${ }^{[4][5][6]}$ One method is fault tree analysis which focuses on one specific failure. It was used in 1961 by AT\&T Bell Laboratories to review the Minuteman missile program. ${ }^{[7]}$ While it is a rigorous method, it becomes unwieldy for a complicated system. A second method is failure mode and effect which focuses on equipment but does not address operator problems. These two techniques generally are applied to component failure and can provide a quantitative estimate of the risk involved. An equipment manufacturer might apply these techniques to certain lines in a gas panel, for example, to determine how much valve redundancy might be needed to reduce the chance of a hazardous gas release to some acceptable level. However, these techniques are not generally applicable to the process as a whole.

We originally started with the "What if?" analysis to structure the PHR. The "What if?" analysis is intuitive. It is easy for the team leader to get the group asking "What if?" questions thereby generating a list of potential hazards. While this analysis can cover a broad range of hazards if the right questions are asked, short cuts will lead to a weak review. The quality of the PHR depends heavily on the experience and background of the team. Too often the "What if?" analysis ended with the question, "What if we didn't ask enough 'What if?' questions?"

Given this vexing question, we turned to the hazard operability (HAZOP) analysis. The HAZOP concept is: systems work well when operating under design conditions and problems arise when deviations from design conditions occur. The HAZOP analysis uses guide words to consider consequences of deviations from design conditions and thereby identify potential hazards, equipment, and process operations problems. Table 1 shows the deviation matrix that contains the guide words interpreted in terms of the design parameters of flow, pressure, temperature, and time. These are the most commonly used design parameters.

Table 1

DEVIATION MATRIX

\begin{tabular}{|c|c|c|c|c|c|c|c|}
\hline $\begin{array}{l}\quad \begin{array}{l}\text { Guide } \\
\text { Words }\end{array} \\
\text { Design } \\
\text { Parameter }\end{array}$ & More of & Less of & None Of & Reverse & Part of & $\begin{array}{c}\text { As Well } \\
\text { As }\end{array}$ & $\begin{array}{l}\text { Other } \\
\text { Than }\end{array}$ \\
\hline Flow & $\begin{array}{l}\text { High } \\
\text { Flow }\end{array}$ & $\begin{array}{l}\text { Low } \\
\text { Flow }\end{array}$ & $\begin{array}{l}\text { No } \\
\text { Flow }\end{array}$ & $\begin{array}{l}\text { Back } \\
\text { Flow }\end{array}$ & $\begin{array}{l}\text { Wrong } \\
\text { Concen- } \\
\text { trations }\end{array}$ & $\begin{array}{l}\text { Contam- } \\
\text { inents }\end{array}$ & $\begin{array}{l}\text { Wrong } \\
\text { Material }\end{array}$ \\
\hline Temperature & $\begin{array}{l}\text { High } \\
\text { Temp }\end{array}$ & $\begin{array}{l}\text { Low } \\
\text { Temp }\end{array}$ & & & & & \\
\hline Pressure & $\begin{array}{l}\text { High } \\
\text { Pressure }\end{array}$ & $\begin{array}{l}\text { Low } \\
\text { Pressure }\end{array}$ & & & & & \\
\hline Time & $\begin{array}{l}\text { Too } \\
\text { Long } \\
\text { Too } \\
\text { Late }\end{array}$ & $\begin{array}{l}\text { Too } \\
\text { Short } \\
\\
\text { Too } \\
\text { Soon }\end{array}$ & $\begin{array}{l}\text { Misses } \\
\text { a Step }\end{array}$ & $\begin{array}{l}\text { Steps } \\
\text { Back- } \\
\text { wards }\end{array}$ & $\begin{array}{l}\text { Some of } \\
\text { Actions } \\
\text { in a Step } \\
\text { Missed }\end{array}$ & $\begin{array}{l}\text { Extra } \\
\text { Actions } \\
\text { Initiated }\end{array}$ & $\begin{array}{l}\text { Wrong } \\
\text { Time }\end{array}$ \\
\hline
\end{tabular}

The HAZOP analysis is a methodical assessment of all deviations from normal and is especially good for new processes where "What if?" type questions do not readily exist because of a lack of experience. However, a complete HAZOP analysis demands a good diagram or model to work from and assumes that the process operates correctly under normal conditions. To be effective, the HAZOP 
analysis demands a strong leader who can keep the group focussed on identifying problems because of deviations from design. As the PHR progresses it is tempting to break out of the HAZOP analysis structure and achieve the satisfaction of finding a solution to the problem.

\subsection{Specific Example}

To illustrate the use of the "What if?" and HAZOP analyses, we have selected as the process equipment an MOCVD reactor that was installed at another AT\&T location. Figure 2 is a schematic representation of the reactor which is an advanced research MOCVD reactor for the deposition of III- $V$ compounds from metai-organic sources.

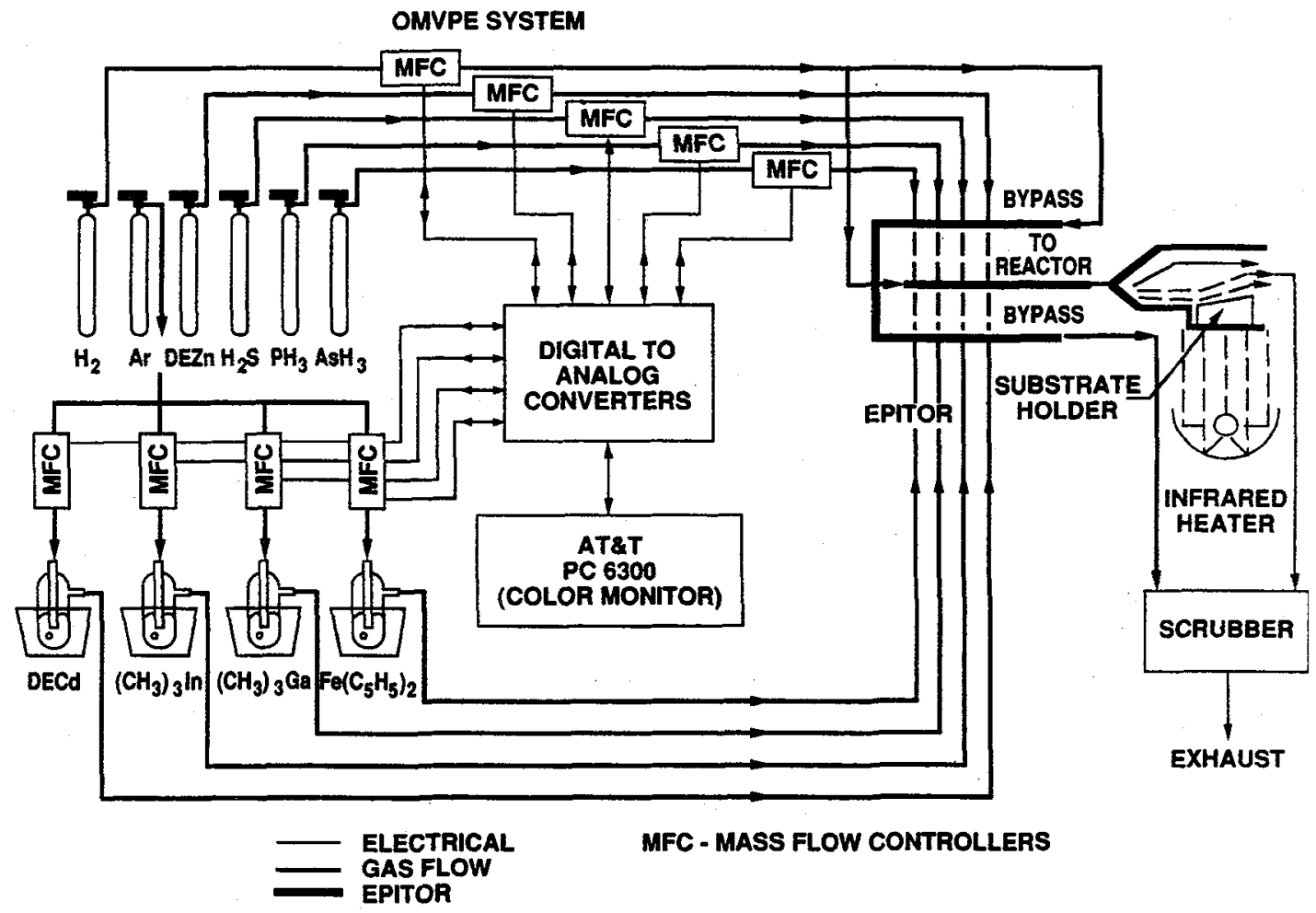

Figure 2

The reactor cell is resistance heated and is supplied under license from British Telecom Research Laboratories who have used it for the deposition of a range of compounds. The standard system accommodates up to four metal-organic sources, five hydride lines, a hydrogen carrier and a vent sweep. The gas system includes a fast switching gas manifold for deposition of abnipt interfaces. Temperature-controlled baths are included in each metal-organic line. The gas flow is controlled by mass flow controllers. The system can be operated manually or optionally by computer control. 
Table 2 shows the "What if?" analysis table that was generated. ${ }^{[8]}$

TABLE 2

\section{WHAT IF? ANALYSIS}

\begin{tabular}{|c|c|c|}
\hline What If & Hazard / Consequence & Control or Action Item \\
\hline $\begin{array}{l}\text { Reactor temperature gets } \\
\text { too high. }\end{array}$ & $\begin{array}{l}\text { Reactor temperature goes to } \\
800^{\circ} \mathrm{C} \text { absolute maximum. }\end{array}$ & $\begin{array}{l}\text { Reactor meltdown occurs at } 1300^{\circ} \mathrm{C} \text {. } \\
\text { No safety hazard. }\end{array}$ \\
\hline Circulating water fails. & $\begin{array}{l}\text { No safety hazard. Water not } \\
\text { used to cool reactor. }\end{array}$ & None. \\
\hline Quartz reactor cracks. & $\begin{array}{l}\text { Gas leak } \\
\text { A. Hydride (toxic release) } \\
\text { B. Hydrogen fire/explosion } \\
\text { C. Inert (no hazard) }\end{array}$ & $\begin{array}{l}\text { A. MDA hydride monitor sounds alarms, } \\
\text { shuts down hydride/hydrogen gas and } \\
\text { purges reactor with inert gas. } \\
\text { B. Action Item (\#1) Install interlocked } \\
\text { hydrogen detectors in each reactor } \\
\text { cabinet. } \\
\text { C. None. }\end{array}$ \\
\hline Air leaks into the reactor. & Possible limited explosion. & $\begin{array}{l}\text { Explosion contained in reactor cabinet. } \\
\text { Subsequent fire/smoke will activate } \\
\text { fire alarm and shut down reactor. }\end{array}$ \\
\hline $\begin{array}{l}\text { Reactor vacuum fails } \\
\text { during sample loading. }\end{array}$ & $\begin{array}{l}\text { Possible fire/explosion } \\
\text { in reactor. }\end{array}$ & $\begin{array}{l}\text { Operator monitors vacuum gauge } \\
\text { to confirm presence of vacuum } \\
\text { before turning reactor hydrogen on. }\end{array}$ \\
\hline $\begin{array}{l}\text { Metal Alkyl bubbler } \\
\text { installed backwards. }\end{array}$ & $\begin{array}{l}\text { Alkyl fire due to liquid entering } \\
\text { reactor and vacuum pump. }\end{array}$ & $\begin{array}{l}\text { Operator verifies the correct bubbler } \\
\text { installation. } \\
\text { Action Item (\#2) } \\
\text { Pursue having supplier label inlet } \\
\text { and outlet connectors. }\end{array}$ \\
\hline $\begin{array}{l}\text { Vacuum is drawn on alkyl } \\
\text { bubbler. }\end{array}$ & $\begin{array}{l}\text { Alkyl vapor (not liquid) will be } \\
\text { drawn into reactor. }\end{array}$ & None. \\
\hline MFC malfunctions & $\begin{array}{l}\text { Hydrogen flow becomes very high } \\
\text { drawing metal alkyl into reactor } \\
\text { with possible alkyl fire. }\end{array}$ & $\begin{array}{l}\text { MFC overflow condition is computer } \\
\text { monitored and system is automatically } \\
\text { shut down. }\end{array}$ \\
\hline $\begin{array}{l}\text { Charcoal scrubber reaches } \\
\text { capacity. }\end{array}$ & $\begin{array}{l}\text { Incipient breakthrough occurs. } \\
\text { Hydrides will be dumped into the } \\
\text { dedicated exhaust system. }\end{array}$ & $\begin{array}{l}\text { Monitor scrubber outlet for hydrides } \\
\text { and replace scrubber as required. }\end{array}$ \\
\hline Oxygen air enters scrubber. & $\begin{array}{l}\text { Scrubber catches fire if there is } \\
\text { unreacted phosphorus present. }\end{array}$ & $\begin{array}{l}\text { Action Item \#3 } \\
\text { Consider scrubber modification enumerated } \\
\text { in the summary of Action Items. }\end{array}$ \\
\hline A chemical spill occurs. & $\begin{array}{l}\text { Personnel burn from chemical } \\
\text { splash or other exposure. }\end{array}$ & $\begin{array}{l}\text { A. Use vented chemical fume load. } \\
\text { B. Spill kits available. } \\
\text { C. Chemical spill button and alarm } \\
\text { available. } \\
\text { D. Eyewashes and showers availabie. }\end{array}$ \\
\hline
\end{tabular}

It consists of three columns: "What if?", "Hazards and Consequences", and "Control or Action Items." Eleven questions were asked that cover a broad range of possible process failures. Examination of the table reveals that it is a useful method but one is left with a sense of incompleteness. For example, what if the power fails? What if a line filter clogs? Faced with these questions we are led to a more structured, systematic analysis, namely the HAZOP analysis.

Table 3 is the HAZOP analysis worksheet for the diethyl cadmium line for the MOCVD reactor. The design intent of this line is to deliver diethyl cadmium to the reactor at the prescribed flow rate. 
TABLE 3

LINE OR VESSEL: DIETHYL CADMIUM (DECd) LINE TO REACTOR

DESIGN INTENT: Deliver DECd to reactor at prescribed flow rate

\begin{tabular}{|c|c|c|c|c|c|}
\hline GUIDE & DEVIATION & CONSEQUENCE & CAUSE & PROTECTION & $\begin{array}{l}\text { RECOMMENDED } \\
\text { ACTION }\end{array}$ \\
\hline More of & High flow & $\begin{array}{l}\text { (1) Poor Product } \\
\text { (2) Not decomposed; } \\
\text { DECd flows } \\
\text { through reactor } \\
\text { into scrubber }\end{array}$ & $\begin{array}{l}\text { (1) Increased } \\
\mathrm{H}_{2} \text { flow } \\
\text { (2) Low reactor } \\
\text { temperature }\end{array}$ & $\begin{array}{l}\text { Check } \\
\text { temperature }\end{array}$ & $\begin{array}{l}\text { Verify temperature } \\
\text { before flow } \\
\text { DECd }\end{array}$ \\
\hline Less of & Low flow & Poor Product & $\begin{array}{l}\text { Reduced } \mathrm{H}_{2} \text { flow } \\
\text { - Faulty MFC } \\
\text { - Clogged Pd } \\
\text { diffuser } \\
-\mathrm{H}_{2} \ll<0 \text { psi }\end{array}$ & . & \\
\hline None of & No flow & Poor Product & $\begin{array}{l}\text { Empty } \mathrm{H}_{2} \text { cylinder } \\
\text { Clogged diffuser } \\
\text { MFC closed }\end{array}$ & & \\
\hline $\begin{array}{l}\text { Reverse } \\
\text { Part of }\end{array}$ & $\begin{array}{l}\text { Back flow } \\
\text { Wrong } \\
\text { Concentration }\end{array}$ & $\begin{array}{l}\text { Poor Product } \\
\text { Decomposed } \\
\text { DECd into } \\
\text { scrubber }\end{array}$ & $\begin{array}{l}\text { High temp. on } \\
\text { DECd }\end{array}$ & $\begin{array}{l}\text { Verify bath } \\
\text { temperature }\end{array}$ & \\
\hline As Well As & Contaminants & $\begin{array}{l}\text { Air-fire } \\
\text { water-fire } \\
\text { decomposition } \\
\text { clog MFC }\end{array}$ & $\begin{array}{l}\text { Air-moisture } \\
\text { Leak into } \\
\text { system at } \\
\text { joint }\end{array}$ & $\begin{array}{l}\text { All welded } \\
\text { No combustible } \\
\text { area }\end{array}$ & $\begin{array}{l}\text { (1) Sprinkler } \\
\text { to cool } \\
\text { bubbler } \\
\text { (2) fire } \\
\text { detector }\end{array}$ \\
\hline $\begin{array}{l}\text { Other } \\
\text { Than }\end{array}$ & $\begin{array}{l}\text { Wrong } \\
\text { material }\end{array}$ & Poor Product & $\begin{array}{l}\text { Mislabeled } \\
\text { cylinder } \\
\text { bubbler line }\end{array}$ & Check lines & \\
\hline
\end{tabular}

Clearly, Table 3 covers only the flow and not the design parameters of temperature, pressure, or time. The complete HAZOP analysis consists of many tables and took several days to complete. It is exhaustive and exhausting.

However, as the PHR team gets more experience, the PHR proceeds more quickly and smoothly. PHRs for similar processes or equipment become easier since the first PHR serves as a template. In addition, it has been our experience that a PHR, performed before the equipment is purchased, actually speeds up installation because the PHR now serves as the initial stage of planning.

From Table 3 we see that most of the deviations result in poor product rather than safety problems. The HAZOP analysis of the PHR is a good way to identify problems with the process. In fact using the HAZOP table, the engineer may be able to determine a process window in which to work to maximize yield.

\section{Conclusions}

We believe that the safety and reliability of semiconductor processes are such important issues that they demand the best techniques to prevent problems from occurring. We described how the HAZOP analysis has been used at AT\&T Bell Laboratories to address these issues. We have given examples of the intuitive "What if?" and rigorous, structured HAZOP analyses applied to an MOCVD reactor. We encourage you to try the PHR questionnaire and either the "What if?" or HAZOP method. 


\section{REFERENCES}

1. The Courier-News, Bridgewater, NJ, March 17, 1988. Three people were killed and one person critically injured when a cylinder of silane contaminated with nitrous oxide exploded.

2. The New York Times, vol. 135, col. 5, p1, January 29, 1986.

3. Dan Petersen, Safety Management: A Human Approach, $2^{\text {nd }}$ edition, Aloray Publisher, 1104 Grand Blvd., Deer Park, NY 11729, 1988.

4. Guidelines for Hazard Evaluation Procedures, American Institute of Chemical Engineers, NY, 1985.

5. Guidelines for Technical Management of Chemical Process Safety, American Institute of Chemical Engineers, NY, 1989.

6. Guidelines for Chemical Process Quantitative Risk Analysis, American Institute of Chemical Engineers, NY, 1989.

7. Process Hazard Management, E. I. duPont de Nemours \& Co., Wilmington, DE, 19898, 1984.

8. E. G. Burkhardt, private communication. 